\title{
Study of the enthalpy-entropy mechanism from water sorption of orange seeds (C. sinensis cv. Brazilian) for the use of agro-industrial residues as a possible source of vegetable oil production
}

\author{
Estudo do mecanismo entálpico-entrópico de sorção da água de sementes de laranja (C. sinensis cv. Brasileira), \\ para a utilização de resíduos agroindustriais como uma possível fonte de produção de óleo vegetal
}

Daniele Penteado ROSA ${ }^{1}$, Harvey Alexander VILLA-VÉLEZ ${ }^{1}$, Javier TELIS-ROMERO ${ }^{1 \star}$

\begin{abstract}
Orange seeds are a promising agroindustry-waste which can be implemented in the extraction and production of vegetable oil. The relationship between moisture content and water activity provides useful information for the processing and storage of this waste item. The aim of this study was to determine the mechanism of water sorption enthalpy-entropy of orange seeds (C. sinensis cv. Brazilians) according to the moisture content. Therefore, desorption isotherms were determined at five different temperature $\left(30,40,50,60\right.$, and $\left.70{ }^{\circ} \mathrm{C}\right)$ under a wide range of moisture content $\left(0.005-0.057 \mathrm{~kg} \mathrm{~kg}^{-1} \mathrm{~d}\right.$.b.) and water activity (0.02-0.756). Theoretical and empirical models were used for modeling the desorption isotherms. An analytical solution of the Clausius-Clapeyron equation was proposed to compute the isosteric heat of sorption, the differential entropy, and Gibbs free energy using the Oswin model when the effect of temperature on the hygroscopic equilibrium was considered.
\end{abstract}

Keywords: sorption isotherms; Oswin model; thermodynamic properties.

\section{Resumo}

As sementes de laranja são resíduos promissores da agroindústria com um alto potencial de aplicação na produção de óleo vegetal. A relação entre o conteúdo de umidade de equilíbrio e a atividade de água fornece informações úteis para seu processamento e armazenamento. O objetivo deste trabalho foi determinar o mecanismo entalpia-entropia de sorção da água de sementes de laranja ( $C$. sinensis cv. Brasileiros) em função do teor de umidade. Para isso, isotermas de dessorção das sementes de laranja foram determinados em cinco níveis de temperaturas $\left(30,40,50,60\right.$ e $\left.70{ }^{\circ} \mathrm{C}\right)$ em um intervalo de umidade de equilíbrio (0.005-0.057 $\mathrm{kg} \mathrm{kg}^{-1}$ d.b.) e atividade de água de 0,02-0,756. Modelos teóricos e empíricos foram usados para a modelagem das isotermas de dessorção. A solução analítica da equação de Clausius-Clapeyron foi proposta para calcular o calor isostérico de sorção, a entropia diferencial e a energia livre de Gibbs através do modelo de Oswin quando o efeito da temperatura sobre o equilíbrio higroscópico foi considerado.

Palavras-chave: isotermas de sorção; modelo de Oswin; propriedades termodinâmicas.

\section{Introduction}

Orange (C. sinensis), the most important of the Citrus fruits, is a tree growing to some $15 \mathrm{~m}$ in height. It perhaps originated in southern China as a hybrid between C. maxima and C. reticulata and was taken to Europe in the fifteenth century. Sweet orange is grown throughout the subtropics and tropics, but Brazil and the United States of America produce the greatest quantities of this fruit. In both countries, the bulk of production is used to manufacture orange juice (VAUGHAN; GEISSLER, 2009). The fruit is a hesperidium, carpels, or segments filled with juicy arils and seeds. Seeds are white, show polyembryony, and vary in size and number in different species. Chemically, sweet oranges contain $6-9 \%$ of total sugars and $44-79 \mathrm{mg} / 100 \mathrm{~g}$ of vitamin C. In addition to being widely consumed as a fresh fruit, its juice is also a good source of sugars, vitamin $\mathrm{C}$, and potassium (DOIJODE, 2001; UNIVERSIDADE..., 2006).
The seeds, commonly considered as agro-industrial waste, are a potential source of vegetable oil and proteins for human consumption. According to El-Adawy and Taha (2001), the orange seed oil has high amount of unsaturated fatty acids (69\%) and essential fatty acids (linoleic + linolenic). Linoleic acid is the major fatty acid present $(38.4 \%)$, followed by oleic (26.0\%), palmitic (29.5\%), and stearic acids (5.3\%). Due to its physicochemical characteristics and fatty acid profile, orange seed oil can be used in food and industrial applications and as na edible oil (AJEWOLE; ADEYEYE, 1993; ANWAR et al., 2008).

Orange seeds show orthodox storage behavior and low tolerance under moisture and chilling conditions. Low temperatures affect seed viability during storage. According to Doijode (2001), seeds stored at $-3.9^{\circ} \mathrm{C}$ for 24 hours were not injured, but they were partially damaged at $-6.7^{\circ} \mathrm{C}$ and

Received 4/8/2012

Accepted 18/10/2012 (00T5817)

Departamento de Engenharia e Tecnologia de Alimentos, Universidade Estadual Paulista - UNESP, CP 136, CEP 15054-000, São José do Rio Preto, SP, Brasil,

e-mail: javier@ibilce.unesp.br

${ }^{*}$ Corresponding author 
completely frost-damaged at $-9.4{ }^{\circ} \mathrm{C}$. Thus, the use of orange seeds can provide extra income and, the same time and help to minimize a waste disposal problem. However, orange seeds deteriorate rapidly under high humidity tropical conditions. Therefore, the drying process can increase the storage time of residues and seeds and prepare the seeds for oil extraction (ANWAR et al., 2008).

Knowing the final moisture content of orange seeds provides information to estimate the energy requirements for processing and optimal conditions of storage and mixture and drying processes(EIM et al., 2011). Enthalpy, entropy, and Gibbs free energy are essential to represent and describe intermolecular reactions and phenomena that occur in some materials. These properties represent, respectively, the amount of energy, the inner or functional order, and the state of chemical equilibrium of the water molecules inside a material. These properties represent respectively the amount of energy, the order or excited state, and the chemical equilibrium of water molecules inside the material (BROVCHENKO; OLEINIKOVA, 2008). The enthalpy-entropy compensation has been an effect widely observed in physical, biological, chemical, and biochemical processes. This theory has a criterion for equilibrium in terms of temperature and pressure. The uniformity of temperature and pressure is the a priori equilibrium conditions (RIZVI, 2005; WILHELM; DAVID; ZUO, 2011).

Changes in some thermodynamic properties with respect to moisture content and temperature can provide a good description of moisture sorption mechanisms and can be used to estimate transitional points between them (GONELLI et al., 2010; SIMAL et al., 2007). In view of the importance of understanding the hygroscopicity of agricultural products, this study aimed to determine the enthalpy-entropy mechanism for orange seeds using sorption isotherms at different temperatures.

\section{Materials and methods}

\subsection{Raw material}

The orange seeds (C. sinensis cv. Brazilians) used in the experimental procedures were obtained directly from fruit juice production lines of industries in São José do Rio Preto, SP, Brazil.

\subsection{Sample preparation}

The seeds were manually separated from the waste and washed with distilled water to remove the remaining pomace. The raw material was stored at $5{ }^{\circ} \mathrm{C}$ for twenty-four hours prior to analysis.

\subsection{Experimental sorption isotherms}

The equilibrium moisture contents of the orange seeds were determined using the static gravimetric method (JOWITT et al., 1987 ) at temperatures of $30,40,50,60$, and $70{ }^{\circ} \mathrm{C}$. The experimental setup consisted of eight hermetic glass jars containing different saturated salt solutions, corresponding to values of relative humidity $(\mathrm{RH})$ from 2.0 to $75.6 \%$. Each jar was filled to a depth of $1.5 \mathrm{~cm}$ with the appropriate salt solution. For each measurement, three replicates of about $1 \mathrm{~g}$ of sample were placed in small plastic containers, which in turn were placed on a support in each jar in order to avoid contact with the salt solution. The jars were subsequently placed in a temperaturecontrolled chamber (BOD, Model TE-391, TECNAL, Brazil) under different temperature and relative humidity conditions, according to the salt used in the jar. The sample weights were controlled until the moisture content on a dry weight basis did not exceed $0.1 \%$, time elapsed-from 4 to 5 weeks, at which equilibrium point was assumed, thus assuring that the water activity of each sample corresponded to relative humidity. For each waste, the initial moisture content was determined according to the AOAC method 926.12 (ASSOCIATION..., 1997) to determine the equilibrium moisture content from the registered weight up to equilibrium. The values obtained for the equilibrium moisture contents, water activities, and temperatures were used to construct the desorption isotherms for the orange seeds.

\subsection{Modeling of sorption isotherms}

The sorption isotherms of orange seeds were simulated using the theoretical model of GAB (Equation 1) and the empirical models of Henderson (Equation 2), Oswin (Equation 3), Halsey (Equation 4) and Iglesias-Chirife (Equation 5). In the models, moisture content was described as a function of both temperature and water activity (EIM et al., 2011; GONELLI et al., 2010)

$$
\begin{aligned}
& X=\frac{X_{m} C K a_{w}}{\left(1-K a_{w}\right)\left[1+(C-1) K a_{w}\right]} \\
& X=\frac{1}{T}\left[\frac{-\log \left(1-a_{w}\right)}{A \cdot B}\right]^{1 / C}
\end{aligned}
$$

$X=(A+B T)\left(\frac{a_{w}}{1-a_{w}}\right)^{1 / C}$

$X=\frac{1}{T}\left[\frac{\exp (A)}{B \log \left(a_{w}\right)}\right]^{1 / C}$

$$
X=(A+B T)\left[\frac{a_{w}}{\left(1-a_{w}\right)}\right]+C
$$

where A, B, C, are the constants of empirical models (dimensionless); $\mathrm{a}_{\mathrm{w}}$ is the water activity; and $\mathrm{X}$ is the equilibrium

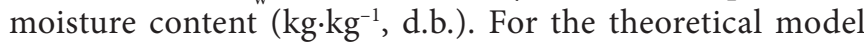
of $\mathrm{GAB}$, the constants $\mathrm{C}$ and $\mathrm{K}$ can be written according to Equations 6 and 7, respectively:

$$
\begin{gathered}
C=C_{0} \exp \left(\frac{H_{m}-H_{n}}{R T}\right) \\
K=K_{0} \exp \left(\frac{\lambda-H_{n}}{R T}\right)
\end{gathered}
$$


where $\mathrm{C}_{0}$ and $\mathrm{K}_{0}$ are GAB model parameters, $\mathrm{H}_{\mathrm{m}}$ and $\mathrm{H}_{\mathrm{n}}$ are the water sorption heats of the monolayer and multilayer $\left(\mathrm{kJ} \cdot \mathrm{mol}^{-1}\right)$, respectively, $\lambda$ is the vaporization energy of pure water $\left(\mathrm{kJ} \cdot \mathrm{mol}^{-1}\right), \mathrm{T}$ is the absolute temperature $(\mathrm{K})$, and $R$ is the ideal gas constant $\left(8.314 \mathrm{~kJ} \cdot \mathrm{K}^{-1} \cdot \mathrm{kmol}^{-1}\right)$ (RIZVI, 2005; TIMMERMANN; CHIRIFE; IGLESIAS, 2001).

\subsection{Enthalpy-entropic mechanism of water sorption}

The enthalpy of sorption was calculated using the ClausiusClayperon equation (Equation 8), and the ASAE Standards (AMERICAN..., 1999) were used to estimate the heat of vaporization of pure water $(\lambda)$ in relation to the temperature:

$Q_{s t}=\lambda-R \frac{\partial\left(\ln a_{w}\right)}{\partial(1 / T)}=\lambda+\frac{R T^{2}}{a_{w}} \frac{\partial a_{w}}{\partial T}$

For this, the best fitted model for the sorption isotherms was used to determine the analytical partial derivative of water activity with respect to temperature, as shown in Equation (8). The calculation of $Q_{s t}$ corresponds to the maximum and minimum temperatures used in the study. This method avoids the linearization between $\ln a_{w} v s .1 / \mathrm{T}$ applied in procedures trough classical mechanics and thermodynamics also known as statistical thermodynamics, in products such as safflower petals and tarragon (KAYA; KAHYAOGLU, 2007), grape leather (KAYA; KAHYAOGLU, 2005), walnut kernels (TOGRUL; ARSLAN, 2007), and corn (CHAYJAN et al., 2010) to calculate the $\mathrm{Q}_{\mathrm{st}}$ at several different moisture content levels.

The differential entropy $(\Delta \mathrm{S})\left(\mathrm{J} \cdot \mathrm{mol}^{-1} \cdot \mathrm{K}^{-1}\right)$ was obtained directly from Equation 9 at the temperatures of 30 and $70^{\circ} \mathrm{C}$ (GONELLI et al., 2010; SIMAL et al., 2007).

$\ln a_{w}=\frac{Q_{s t}}{R T}-\frac{\Delta S}{R}$

The same procedure was performed for the Gibbs free energy $(\Delta \mathrm{G})\left(\mathrm{J} \cdot \mathrm{mol}^{-1}\right)$ using Equation 10:

$\Delta G=R T \ln a_{w}$

According to Mulet et al. (2002) and García-Pérez et al. (2008) $\Delta \mathrm{G}$ is known as thermodynamic potential, which measures the "useful" or process-initiating work obtainable from an isothermal, isobaric thermodynamic system. Just as in mechanics, where potential energy is defined as capacity to do work, similarly different potentials have different meanings.

According to the compensation theory (KRUG; HUNTER; GRIEGER, 1976a, b), the linear relationship between enthalpy and entropy is defined by the Gibbs free energy. Changes in $\Delta \mathrm{G}$ values provide a criterion to evaluate whether water sorption is a spontaneous $(\Delta G \beta<0)$ or non-spontaneous process $(\Delta G \beta>0)$ (RIZVI, 2005; TELIS et al., 2000).

\subsection{Estimation of the parameters and statistical analysis}

The parameters of the theoretical and empirical models (Equations 1-7) were estimated by fitting the equations to the experimental data using the "nlinfit" function of the Statistic
Toolbox of Matlab 7.1 (The MathWorks Inc., Natick, MA, USA) and considering the "robust" fitting option. This function uses the Gauss-Newton algorithm with Levenberg-Marquardt modifications that iteratively reweighs the response values and re-computes a least-square fit of a non-linear model. The $95 \%$ confidence intervals of the estimated theoretical and empirical parameters were determined by using the "nlparci" function of the same Matlab Toolbox.

The adjusted value of $R^{2}$ and the root mean square error (RMSE) (Equation 12) were used to assess the model accuracy. The statistical parameter $R_{a d j}^{2}$ (Equation 11) minimizes the estimated variance of the errors and, the RMSE is a measure of the standard error in the estimation (SHESKIN, 2004).

$$
R_{a d j}^{2}=\frac{1-\left(1-R^{2}\right)(N-1)}{(N-M-1)}
$$

$R M S E=\left[\frac{1}{N} \sum_{k=1}^{N}\left(y_{k}-y_{k}^{*}\right)^{2}\right]^{1 / 2}$

In Equations 11 and 12, $y$ represents the experimental values; $y^{*}$ represents the estimated values, $\bar{y}$ is the average of the experimental values, $N$ is the number of experimental values, $M$ is the number of independent variables, and $R^{2}$ is the coefficient of determination.

\section{Results and discussion}

\subsection{Experimental sorption isotherms}

The equilibrium moisture content of orange seeds was determined experimentally using a statically gravimetric method. Results of the average equilibrium moisture content $\left(\mathrm{X}_{\mathrm{e}}\right)$ along with the standard deviation are shown in Table 1. These results correspond at five temperature levels of 30,40, 50,60 , and $70^{\circ} \mathrm{C}$ in the range of $2.00-75.6 \%$ relative humidity.

In Table 1, it can be observed a decrease in $\mathrm{X}_{\mathrm{e}}$ when the temperature increases for each level of water activity. According to Rizvi (2005), at higher temperature water molecules reach higher energy levels and this allows them break away from their sorption sites, thus decreasing the equilibrium moisture content. As temperature changes, the excitation of molecules, as well as the distance, and thus attraction between molecules varies. This causes the amount of sorbed water to change with temperature at a given water activity.

The experimental equilibrium moisture content of orange seeds ranged from 0.005 to 0.057 , showing a similar tendency to that of other oleaginous seeds such as sesame (KAYA; KAHYAOGLU, 2006), peanut pods (CORRÊA et al., 2007) and amaranth grains (PAGANO; MASCHERONI, 2005). These values indicate that the intact seeds do not readily adsorb moisture, a property that contributes to a longer shelf life.

\subsection{Modeling the sorption isotherms}

The identified values for the GAB model parameters with the $95 \%$ confidence intervals are shown in Table 2. Table 3 
Table 1. Experimental equilibrium moisture contents for the orange seeds ${ }^{\mathrm{a}}$ at temperatures ranging from 30 to $70^{\circ} \mathrm{C}$.

\begin{tabular}{|c|c|c|}
\hline $\mathrm{T}$ & $a_{w}$ & $X_{e}$ \\
\hline \multirow{8}{*}{30} & 0.069 & $0.012 \pm 0.000$ \\
\hline & 0.112 & $0.015 \pm 0.001$ \\
\hline & 0.223 & $0.024 \pm 0.001$ \\
\hline & 0.324 & $0.029 \pm 0.001$ \\
\hline & 0.439 & $0.036 \pm 0.001$ \\
\hline & 0.526 & $0.043 \pm 0.003$ \\
\hline & 0.635 & $0.047 \pm 0.001$ \\
\hline & 0.756 & $0.057 \pm 0.002$ \\
\hline \multirow{8}{*}{40} & 0.066 & $0.010 \pm 0.000$ \\
\hline & 0.111 & $0.014 \pm 0.001$ \\
\hline & 0.206 & $0.019 \pm 0.001$ \\
\hline & 0.319 & $0.024 \pm 0.001$ \\
\hline & 0.432 & $0.030 \pm 0.001$ \\
\hline & 0.506 & $0.036 \pm 0.002$ \\
\hline & 0.615 & $0.039 \pm 0.000$ \\
\hline & 0.753 & $0.051 \pm 0.002$ \\
\hline \multirow{8}{*}{50} & 0.059 & $0.011 \pm 0.000$ \\
\hline & 0.110 & $0.013 \pm 0.001$ \\
\hline & 0.189 & $0.018 \pm 0.001$ \\
\hline & 0.314 & $0.023 \pm 0.001$ \\
\hline & 0.432 & $0.028 \pm 0.001$ \\
\hline & 0.489 & $0.033 \pm 0.002$ \\
\hline & 0.599 & $0.036 \pm 0.001$ \\
\hline & 0.746 & $0.043 \pm 0.001$ \\
\hline \multirow{8}{*}{60} & 0.045 & $0.007 \pm 0.000$ \\
\hline & 0.110 & $0.011 \pm 0.001$ \\
\hline & 0.175 & $0.014 \pm 0.001$ \\
\hline & 0.307 & $0.018 \pm 0.000$ \\
\hline & 0.432 & $0.022 \pm 0.001$ \\
\hline & 0.473 & $0.025 \pm 0.002$ \\
\hline & 0.590 & $0.027 \pm 0.000$ \\
\hline & 0.740 & $0.033 \pm 0.001$ \\
\hline \multirow{8}{*}{70} & 0.020 & $0.005 \pm 0.000$ \\
\hline & 0.110 & $0.009 \pm 0.000$ \\
\hline & 0.162 & $0.012 \pm 0.000$ \\
\hline & 0.294 & $0.015 \pm 0.000$ \\
\hline & 0.432 & $0.020 \pm 0.000$ \\
\hline & 0.458 & $0.021 \pm 0.001$ \\
\hline & 0.587 & $0.024 \pm 0.000$ \\
\hline & 0.739 & $0.029 \pm 0.000$ \\
\hline
\end{tabular}

${ }^{a}$ Mean and standard deviation for three replicates. T: temperature $\left({ }^{\circ} \mathrm{C}\right) ; \mathrm{X}_{e}$ : experimental equilibrium moisture content $\left(\mathrm{kg} \mathrm{kg}^{-1}\right.$ d.b.); and $\mathrm{a}_{\mathrm{w}}$ : water activity (dimensionless).

shows the values for the empirical models parameters and their statistical validations. The confidence intervals for these models at the 95\% confidence level are shown in Table 4. The statistical results show only three models that meet a satisfactory agreement between the experimental and estimated values. The Oswin, Henderson and GAB models, show the best fit to the experimental data of orange seeds, with adjusted value of $R^{2}$ of $0.983,0.978$ and 0.977 , respectively.

In Tables 3 and 4, it can be observed that the Oswin model presented slightly better results, the root mean square error from the regression was lower than that of other models $\left(\mathrm{RMSE}=1.589 \times 10^{-3}\right)$. Oswin's equation has been widely applied to foodstuffs such as seeds and grains, but when compared to the GAB model and other empirical models, its applicability was found to be less versatile (BARBOSA-CÁNOVAS et al., 2007; TIMMERMANN; CHIRIFE; IGLESIAS, 2001). In terms of specificity, the Oswin model is advantageous due to its suitability to represent the entire isotherm of desorption in different temperatures at lows moisture content and water activity. In this study, the values of the empirical parameters of the Oswin's model were calculated as a function of temperature. Figure 1 shows a closed sigmoidal curve, characteristic of products with low water content (RIZVI, 2005). Also, due to the goodness of fit of the model, very close values were observed between simulated and experimental data of moisture content. As previously mentioned, this model is recommended for estimating the $\mathrm{X}_{e}$ of orange seeds. Some studies that investigated sorption isotherms of products such as rice grain (DA-WEN, 1999), yellow dent corn (SIMBARASHE et al., 2007), pea seeds (CHEN, 2003), broad been seeds (MENKOV, 2000), and pearl millet grain (GONELLI et al., 2010) suggest that the Oswin model is one of the most appropriate models to describe the hygroscopicity phenomenon for foodstuffs with low moisture contents.

\subsection{Enthalpy-entropic mechanism of water sorption}

The Clausius-Clapeyron equation (Equation 8 ) was used to compute the isosteric heat of sorption $\left(Q_{s t} \mathrm{~kJ} \cdot \mathrm{mol}^{-1}\right)$ for orange seeds using the partial derivative of water activity with respect to the temperature (Equation 14), from its analytical solution (Equation 13) and the Oswin model parameters (Equation 3).

$$
a_{w}=\frac{1}{\left[\frac{X}{(A+B / T)}\right]^{-C}+1}
$$

$$
\frac{\partial a_{w}}{\partial T}=\frac{\left[B C\left(\frac{T X}{B+A T}\right)^{C}\right]}{\left\{T\left[\left(\frac{T X}{B+A T}\right)^{C}+1\right]\right\}^{2}(B+A T)}
$$

The isosteric heat of sorption found at temperatures of 30 and $70^{\circ} \mathrm{C}$ and equilibrium moisture content between 0.005 to $0.08 \mathrm{~kg} \cdot \mathrm{kg}^{-1}$ (d.b) are shown in Figure 2. The $Q_{\mathrm{st}}$ values decreased as the moisture content increased and were close to the water vaporization energy at moisture contents over $0.050 \mathrm{~kg} \cdot \mathrm{kg}^{-1}$ (d.b). In the graph, intersections of values of $Q_{s t}$ at the moisture content of $0.021 \mathrm{~kg} \cdot \mathrm{kg}^{-1}$ (d.b) were observed. This can be explained quantitatively by considering that at low moisture contents and high temperatures, sorption occurs at the most active available sites giving rise to great interaction energy. The initial values for the isosteric heat of sorption at temperature of $70{ }^{\circ} \mathrm{C}$ may have resulted from the chemisorption on polar groups and the high rate of evaporation of water caused by the reaction of lipids and aromatic components of orange seeds. Kartika et al. (2012) describe that deteriorative changes in oilseeds may be either oxidative or hydrolytic, resulting in the 
Table 2. Estimated parameters, statistical validation, and intervals confidence of the GAB model parameters.

\begin{tabular}{|c|c|c|c|c|c|c|c|}
\hline \multirow{2}{*}{ Model } & \multicolumn{5}{|c|}{ Parameters } & \multirow{2}{*}{$\mathrm{R}_{\text {adj }}^{2}$} & \multirow{2}{*}{ RMSE } \\
\hline & $\mathrm{X}_{\mathrm{m}}$ & $\mathrm{C}_{0}$ & $\mathrm{~K}_{0}$ & $\mathrm{H}_{\mathrm{m}}$ & $\mathrm{H}_{\mathrm{n}}$ & & \\
\hline \multirow[t]{4}{*}{ GAB } & $2.678 \times 10^{-2}$ & 0.087 & 0.754 & 56.686 & 43.740 & 0.978 & $1.764 \times 10^{-3}$ \\
\hline & \multicolumn{5}{|c|}{$95 \%$ confidence intervals } & & \\
\hline & $2.234 \times 10^{-2}$ & -0.340 & -0.597 & 39.749 & 39.357 & & \\
\hline & $3.122 \times 10^{-2}$ & 0.516 & 2.105 & 73.622 & 48.123 & & \\
\hline
\end{tabular}

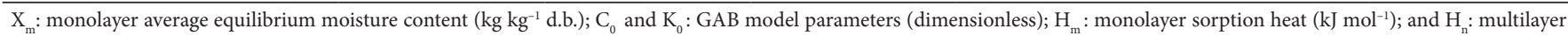
sorption heat $\left(\mathrm{kJ} \mathrm{mol}^{-1}\right)$.

Table 3. Estimated parameters and statistical validation for the empirical models.

\begin{tabular}{lcccrr}
\hline \multirow{2}{*}{ Models } & \multicolumn{3}{c}{ Parameters } & \multirow{2}{*}{$\mathrm{R}_{\text {adj }}^{2}$} & \multirow{2}{*}{ RMSE } \\
\cline { 2 - 4 } & $\mathrm{A}$ & $\mathrm{B}$ & $\mathrm{C}$ & 0.977 & $1.838 \times 10^{-3}$ \\
Henderson & $19.088\left(\mathrm{k}^{-1}\right)$ & -281.92 & 1.983 & 0.983 & $1.579 \times 10^{-3}$ \\
Oswin & 0.16977 & $-4,3462 \times 10^{4}\left(\mathrm{k}^{-1}\right)$ & 2.6682 & 0.951 & $2.679 \times 10^{-3}$ \\
Halsey & 1.930 & $-2.729 \times 10^{-2}\left(\mathrm{k}^{-1}\right)$ & 1.813 & 0.840 & $4.901 \times 10^{-3}$ \\
Iglesias \& Chirife & 0.109 & $-3.028 \times 10^{-4}\left(\mathrm{k}^{-1}\right)$ & $1.469 \times 10^{-2}$ & \\
\hline
\end{tabular}

A, B, C: empirical model parameters.

Table 4. Confidence intervals for the empirical model parameters.

\begin{tabular}{lccc}
\hline \multirow{2}{*}{ Model } & \multicolumn{3}{c}{} \\
\cline { 2 - 4 } & $\mathrm{A}$ & 95\% Confidence intervals & C \\
\hline Henderson & 8.421 & -286.470 & 1.846 \\
& 29.755 & -277.380 & 2.120 \\
Oswin & -0.124 & 41.039 & 2.522 \\
& -0.098 & 49.461 & 2.814 \\
Halsey & 0.400 & $-3.280 \times 10^{-2}$ & 1.641 \\
& 3.460 & $-2.177 \times 10^{-2}$ & 1.985 \\
Iglesias \& Chirife & 0.077 & $-4.017 \times 10^{-4}$ & $1.220 \times 10^{-2}$ \\
& 0.141 & $-2.039 \times 10^{-4}$ & $1.717 \times 10^{-2}$ \\
\hline
\end{tabular}

A, B, C: empirical model parameters.

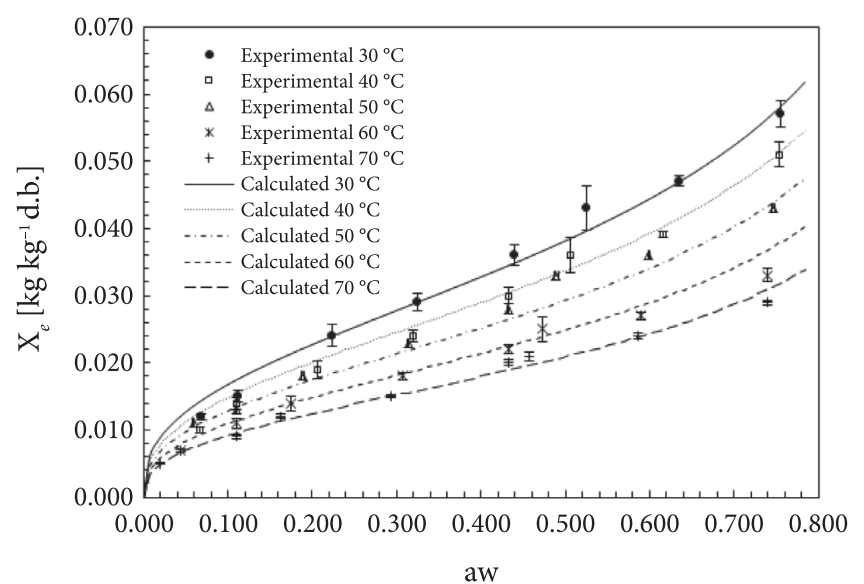

Figure 1. Experimental sorption isotherms for orange seeds at 30, 50, and $70^{\circ} \mathrm{C}$ and the results estimated with the Oswin model.

production of free fatty acids. Fats in seeds were readily broken by lipases into free fatty acids and glycerol during storage, particularly when the temperature is high. In the intersection point, temperature of $70{ }^{\circ} \mathrm{C}$ accelerated desorption because of high lipolytic activity of the molecules and, as can be seen,

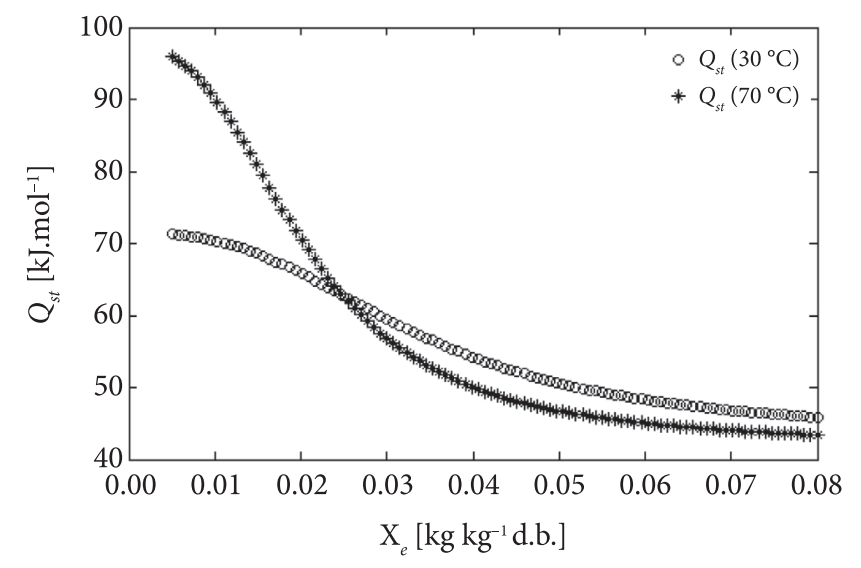

Figure 2. Isosteric heat of sorption for water desorption from the orange seeds, at temperatures of 30 and $70^{\circ} \mathrm{C}$, as a function of moisture content.

values above to $0.021 \mathrm{~kg} \cdot \mathrm{kg}^{-1}$ (d.b) are very close to each other, demonstrating that the desorption process for orange seeds is influenced by the composition and temperature.

Natural logarithm curves of water activity as a function of the reciprocal of the absolute temperature $(\mathrm{K})$ were constructed 


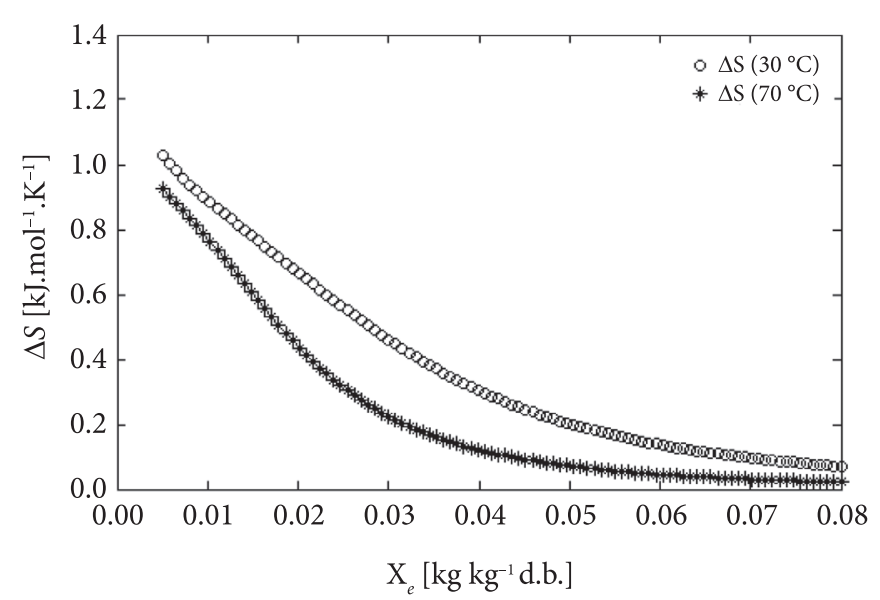

Figure 3. Differential entropy for water desorption from the orange seeds, as a function of moisture content.

for moisture content (d.b) between 0.057 and $0.005 \mathrm{~kg} \mathrm{~kg}^{-1}$ (d.b), found by linear regression of the excess values of the total heat of sorption $\left(Q_{s t}\right)$, which are the respective values of the linear coefficients of each curve multiplied by the universal gas constant. The heat of sorption isosteric $\left(q_{s t}\right)$ is defined as the difference between the total heat of sorption isosteric $\left(Q_{s t}\right)$ and the latent heat of vaporization of water at the same temperature.

Figure 3 shows the evolution of differential entropy with the moisture content at temperatures of 30 and $70{ }^{\circ} \mathrm{C}$. Differential entropy represents the algebraic sum of the integral entropy at a particular hydration level, plus the change of order or disorder after new water molecules are adsorbed by the system at the same hydration level. In the present study, values of $\Delta S$ ranged from 1.327 to $0.249\left(\mathrm{~kJ} \cdot \mathrm{mol}^{-1} \cdot \mathrm{K}^{-1}\right)$ and 0.829 to $0.046\left(\mathrm{~kJ} \cdot \mathrm{mol}^{-1} \cdot \mathrm{K}^{-1}\right)$ at the temperatures of 30 and $70{ }^{\circ} \mathrm{C}$, respectively. These values correspond to the maximum and minimum differential entropy, at which it is possible to observe changes in the ordering of the adsorbed water molecules on the seeds when increasing the moisture content. According to Chinachoti (1998), the sorption isotherm was suspected to affect seed properties because water acting as a solvent seems to impart mobility to chemical constituents of seeds by dissolution. This will account for the increased rate of chemical reaction, and it was accelerated by temperature, relative humidity, and initial seed moisture content. Since fatty acids are carboxylic acids released from triglycerides by lipase or effect oxidation, these effects must be studied when the seeds are subjected to temperature increases because oxidation is a function of the content of saturated and unsaturated fatty acids that are especially sensitive (SILVA; BORGES; FERREIRA, 1999).

To confirm the enthalpy-entropy mechanism, Figure 4 shows values of Gibbs free energy $\left(\Delta \mathrm{G}, \mathrm{kJ} \cdot \mathrm{mol}^{-1}\right)$ at temperatures of 30 and $70^{\circ} \mathrm{C}$.

The $\Delta \mathrm{G}$ values ranged from -13.701 to $-0.747\left(\mathrm{~kJ} \cdot \mathrm{mol}^{-1}\right)$ and -10.939 to $-0.188\left(\mathrm{~kJ} \cdot \mathrm{mol}^{-1}\right)$ at temperatures of 30 and $70{ }^{\circ} \mathrm{C}$, respectively. These values are very close to each other considering the temperatures investigated; all values were smaller than zero. The $\Delta G$ results indicate that water sorption

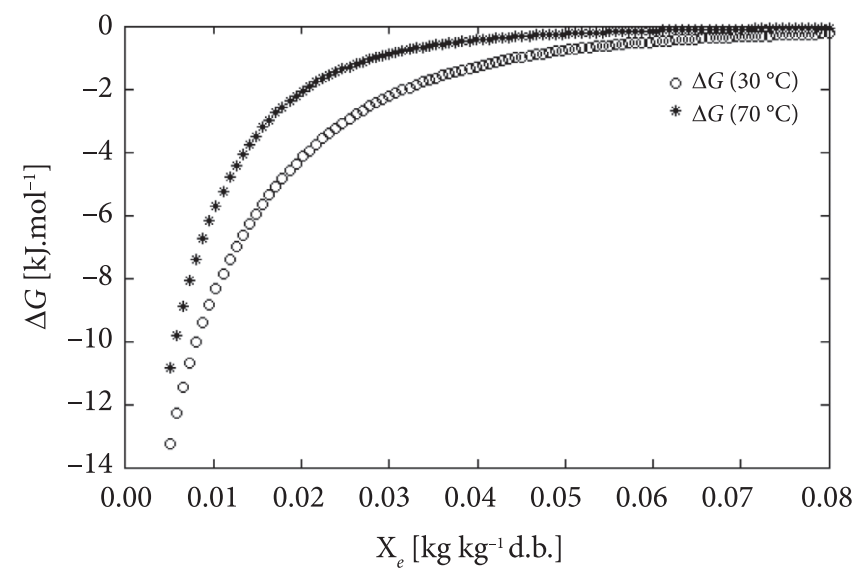

Figure 4. Gibbs free energy for water desorption from the orange seeds, as a function of moisture content.

occurred in a spontaneous process. Moreover, the values showed that the reactions occurring in the microstructure of the product would be stable under the temperature range of $30-70{ }^{\circ} \mathrm{C}$. In general terms, Figures 2 and 3 showed stronger intermolecular interactions or bonding (related to the enthalpy), which would lead to a greater reduction in the freedom of configuration and hence to a greater order of the system (related to the entropy). This relationship might allow for the application of the enthalpyentropy compensation theory to the orange seeds since the reaction rate should be similar for all reactions occurring at the temperatures evaluated (VILLA-VÉLEZ et al., 2012).

\section{Conclusions}

Sorption isotherms for the orange seeds were experimentally determined at $30,40,50,60$ and $70^{\circ} \mathrm{C}$ in a wide range of water activity and moisture content values. The Oswin model was used to adequately represent the desorption data at the studied temperatures. The Oswin model can be used to determine the analytical partial derivative of the water activity as a function of temperature to calculate the isoteric heat of sorption for water using the Clausius-Clapeyron equation in order to determine the isosteric heat of sorption of the water. The application of the above methodology allowed the analytical calculation of $Q_{s t}$, avoiding the linearization between $a_{w}$ versus $1 / T$ as proposed and used by several other authors. Moreover, the values for $\Delta S$ and $\Delta \mathrm{G}$ were also calculated directly in the moisture content range of the isotherm desorption. The analyses of $Q_{s t}$ and $\Delta S$ results suggest the need of further research on the influence of fatty acids contents on the sorption isotherms for orange seeds. Finally, the enthalpy-entropy compensation suggested a thermodynamic equilibrium, in which, from an analysis of $\Delta G$ in the same moisture contents range, a spontaneous process was observed.

\section{Acknowledgements}

The authors are grateful to the Sao Paulo State Research Support Agency, FAPESP for the financial support (process 2011/05094-8). 


\section{References}

AJEWOLE, K.; ADEYEYE, A. Characterisation of Nigerian citrus seed oils. Food Chemistry, v. 47, p. 77-78, 1993. http://dx.doi. org/10.1016/0308-8146(93)90306-Z

AMERICAN SOCIETY OF AGRICULTURAL ENGINEERS - ASAE. Psychrometric data D271.2 DEC99. ASAE. 1999.

ANWAR, F. et al. Physico-chemical characteristics of ciitrus seeds and seed oils from Pakistan. Journal of American Oil Chemists' Society, v. 85, p. 321-330, 2008.

ASSOCIATION OF OFFICIAL ANALYTICAL CHEMISTS - AOAC. Offical Methods of Analysis of AOAC International. 16th ed. Gaithersburg: International AOAC, 1997.

BARBOSA-CÁNOVAS, G. V. et al. Water activity in foods: fundamentals and applications. Ames: Blackwell Publishing Profesional, 2007. 438 p. Pmid:17961286. http://dx.doi.org/10.1002/9780470376454

BROVCHENKO, I.; OLEINIKOVA, A. Interfacial and confined water. Oxford: Elsevier, 2008. 317 p.

CHAYJAN, R. A. et al. Mathematical modelling of corn thermodynamic properties for desorption energy estimation. International Agrophysics, v. 24, p. 213-218, 2010.

CHEN, C. Moisture sorption isotherms of pea seeds. Journal of Food Engineering, v. 58, p. 45-51, 2003. http://dx.doi.org/10.1016/S02608774(02)00332-1

CHINACHOTI, P. Water migration and food storage stability. In: TAUB, I. A.; SINGH, R. P. (Eds.). Food storage stability. New York: CRC Press, 1998. cap. 9, p. 1-23.

CORRÊA, P. C. et al. Sorption isotherms and isosteric heat of peanut pods, kernel and hulls. Food Science and Technology International, v. 13, n. 3, p. 231-238, 2007. http://dx.doi. org/10.1177/1082013207079601

DA-WEN, S. Comparison and selection of EMC/ERH isotherm equations for rice. Journal of Stored Products Research, v. 35, p. 249-264, 1999. http://dx.doi.org/10.1016/S0022-474X(99)00009-0

DOIJODE, S. D. Seed Storage of Horticultural Crops. New York: Food Products Press, 2001. 357 p.

EIM, V. S. et al. Moisture sorption isotherms and thermodynamic properties of carrot. International Journal of Food Engineering, v. 7, n. 3, p. 1-18, 2011. http://dx.doi.org/10.2202/1556-3758.1804

EL-ADAWY, T. A.; TAHA, K. M. Characteristics and composition of different seed oils and flours. Food Chemistry, v. 74, p. 47-54, 2001. http://dx.doi.org/10.1016/S0308-8146(00)00337-X

GARCÍA-PÉREZ, J. V. et al. Water sorption isotherms for lemon peel at different temperatures and isosteric heats. LWT - Food Science and Technology, v. 41, p. 18-25, 2008.

GONELLI, A. L. D. et al. Water sorpotion isotherms and thermodynamic properties of pearl millet grain. International Journal of Food Science and Technology, v. 45, p. 828-838, 2010. http://dx.doi. org/10.1111/j.1365-2621.2010.02208.x

JOWITT, R. et al. Physical properties methods of foods. 2nd ed. London: Applied Science Publishers, 1987. 564 p.

KARTIKA, I. A. et al. Moisture sorption behaviour of jatropha seeds (jatropha curvas) as a source of vegetable oil biodiesel production. Biomass and Bioenergy, v. 36, p. 226-233, 2012. http://dx.doi. org/10.1016/j.biombioe.2011.10.026

KAYA, S.; KAHYAOGLU, T. Influence of dehulling and roasting process on the thermodynamics of moisture adsorption in sesame seed. Journal of Food Engineering, v. 76, p. 139-147, 2006. http:// dx.doi.org/10.1016/j.jfoodeng.2005.04.042

KAYA, S.; KAHYAOGLU, T. Thermodynamic properties and sorption equilibrium of pestil (grape leather). Journal of Food Engineering, v. 71, p. 200-207, 2005. http://dx.doi.org/10.1016/j. jfoodeng.2004.10.034
KAYA, S.; KAHYAOGLU, T. Moisture sorption and thermodynamic properties os safflower petals and tarragon. Journal of Food Engineering, v. 78, p. 413-421, 2007. http://dx.doi.org/10.1016/j. jfoodeng.2005.10.009

KRUG, R. R.; HUNTER, W. G.; GRIEGER, R. A. Enthalpy-entropy compensation. 1. Some fundamental statistical problems associated with the analysis of Von't Hoff and Arrhenius data. Journal of Physical Chemistry, v. 80, p. 2335-2341, 1976a. http://dx.doi. org/10.1021/j100562a006

KRUG, R. R.; HUNTER, W. G.; GRIEGER, R. A. Enthalpy-entropy compensation. 2. Separation of the chemical from the statistical effect. Journal of Physical Chemistry, v. 80, p. 2341-2351, $1976 \mathrm{~b}$. http://dx.doi.org/10.1021/j100562a007

MENKOV, N. D. Moisture sorption isotherms of broan bean seeds. Nahrung, v. 44, p. 443-446, 2000. http://dx.doi.org/10.1002/15213803(20001201)44:6<3C443::AID-FOOD443>3E3.0.CO;2-1

MULET, A. et al. Equilibrium isotherms and isoteric heats of morel (Morchela esculenta). Journal of Food Engineering, v. 53, p. 75-81, 2002. http://dx.doi.org/10.1016/S0260-8774(01)00142-X

PAGANO, A. M.; MASCHERONI, R. H. Sorption isotherms for amaranth grains. Journal of Food Engineering, v. 67, p. 441-450, 2005. http://dx.doi.org/10.1016/j.jfoodeng.2004.05.012

RIZVI, S. S. H. Thermodynamic Properties of Foods in Dehydration. In: RAO, M. A.; RIZVI, S. S. H.; DATTA, A. K. (Eds.). Engineering Properties of Foods. 3rd ed. Boca Raton: Taylor \& Francis Group, 2005. cap. 7, p. 1-88.

SHESKIN, D. Handbook of parametric and nonparametric statistical procedures. 3rd ed. Boca Raton: Taylor \& Francis Group, 2004. 972 p.

SILVA, F. A. M.; BORGES, M. F. M.; FERREIRA, M. A. Methods for the evaluation of the degree of lipid oxidation and the antioxidant activity. Química Nova, v. 22, n. 1, p. 94-103, 1999. http://dx.doi. org/10.1590/S0100-40421999000100016

SIMAL, S. et al. Water desorption thermodynamic properties of pineapple. Journal of Food Engineering, v. 80, p. 1293-1301, 2007. http://dx.doi.org/10.1016/j.jfoodeng.2006.10.001

SIMBARASHE, S. et al. Sorption isotherms and isosteric heats of sorption of whole yellow dent corn. Journal of Food Engineering, v. 79, p. 168-175, 2007. http://dx.doi.org/10.1016/j. jfoodeng.2006.01.040

TELIS, V. R. N. et al. Water sorption thermodynamic properties applied to persimmon skin and pulp. Thermochimica Acta, v. 343, p. 49-56, 2000. http://dx.doi.org/10.1016/S0040-6031(99)00379-2

TIMMERMANN, E. O.; CHIRIFE, J.; IGLESIAS, H. A. Water sorption isotherms of foods and foodstuffs: BET or GAB parameters? Journal of Food Engineering, v. 48, p. 19-31, 2001. http://dx.doi. org/10.1016/S0260-8774(00)00139-4

TOGRUL, H.; ARSLAN, N. Moisture sorption isotherms and thermodynamic properties of walnut kernels. Journal of Stored Products Research, v. 43, p. 252-264, 2007. http://dx.doi. org/10.1016/j.jspr.2006.06.006

UNIVERSIDADE ESTADUAL DE CAMPINAS - UNICAMP. Tabela brasileira de composição de alimentos - TACO. versão 2. 2. ed. Campinas: UNICAMP/NEPA, 2006.

VAUGHAN, J. G.; GEISSLER, C. A. The new oxford book of food plants. 4th ed. New York: Oxford University Press, 2009. 284 p.

VILLA-VÉLEZ, H. A. et al. Modelling thermodynamic properties of banana waste by analytical derivation of desorption isotherms. International Journal of Food Engineering, v. 8, n. 1, p. 1-21, 2012. http://dx.doi.org/10.1515/1556-3758.2191

Wilhelm, N. A.; DAVID, R.; ZUO, Y. Applied surface thermodynamics. 2nd ed. Boca Raton: CRC Press: Taylor \& Francis Group, 2011. 768 p. 